\title{
Surgical Outcome of Revision Operation for Recurrent Aural Cholesteatoma
}

\author{
Ji Soo Lee, Ju Ho Han, Sung Kwang Hong, Hyo Jeong Lee, and Hyung-Jong Kim iD \\ Department of Otorhinolaryngology-Head and Neck Surgery, Hallym University College of Medicine, Anyang, Korea
}

\author{
재발한 진주종에 대한 재수술 결과 \\ 이지수 · 한주호 · 홍성광 · 이효정 · 김형종 \\ 한림대학교 의과대학 이비인후-두경부외과학교실
}

\author{
Received November 16, 2019 \\ Revised December 30, 2019 \\ Accepted January 10, 2020 \\ Address for correspondence \\ Hyung-Jong Kim, MD, PhD \\ Department of Otorhinolaryngology- \\ Head and Neck Surgery, \\ Hallym University \\ Sacred Heart Hospital, \\ 22 Gwanpyeong-ro 170beon-gil, \\ Dongan-gu, Anyang 14068, Korea \\ Tel $+82-31-380-3842$ \\ Fax +82-31-386-3860 \\ E-mail hjk1000@hallym.or.kr
}

Background and Objectives To investigate surgical outcomes of revision operation for recurrent cholesteatoma.

Subjects and Method From 1989 to 2018, 5245 cases of middle ear surgeries were performed at Kangdong and Hallym University Sacred Heart Hospital. A total of 138 clinical records of the subjects who underwent revision cholesteatoma surgery, and whose follow-up durations were more than 3 months, were reviewed. Hearing outcomes were analyzed in accordance with the 2005 Korean otology society guideline. Postoperative perforation was defined to be present if perforation exists after three months of surgery. Postoperative infection or recurrence was defined if patients were treated with intravenous antibiotics or underwent reoperation.

Results Among 138 cases, surgical approaches used were canal wall up mastoidectomy in 38 (28\%), canal wall down mastoidectomy in $89(64 \%)$, and exploratory tympanotomy in $11(8 \%)$. Air conduction and air bone gap showed statistically significant differences before and after the surgery. The number of patients who met at least 1 criteria was 70 , accounting for $51 \%$. Patients were classified into four groups according to the Postoperative ABG grade, where $43 \%$ of patients were included in "Excellent" or "Good" results group. When the results were compared according to the surgical method, canal wall up group showed significantly higher hearing success rate compared to CWDM group. Patients without postoperative perforation, infection or recurrence were considered successful and there were 122 such cases, accounting for $88 \%$. Conclusion CWDM more frequently underwent revision than CWUM and ET, and showed worse hearing results than other groups. These analyses can be used for preoperative counseling. Korean J Otorhinolaryngol-Head Neck Surg 2021;64(3):148-54

Key Words Cholesteatoma $\cdot$ Otitis media $\cdot$ Recidivism $\cdot$ Reoperation.

\section{서 론}

국내에서 만성중이염의 유병률은 전체인구의 $2.19 \%$ 이고, 그 중 진주종은 $1.18 \%$ 를 차지하는 것으로 보고되었고, ${ }^{1,2)}$ 진 주종은 진행된 병변에서 심각한 두개내 합병증을 초래할 수

This is an Open Access article distributed under the terms of the Creative Commons Attribution Non-Commercial License (https://creativecommons.org/licenses/by-nc/4.0) which permits unrestricted non-commercial use, distribution, and reproduction in any medium, provided the original work is properly cited.
있기 때문에 일반적으로 수술적인 제거가 필요한 질환이다. ${ }^{3)}$ 진주종은 임상적으로 선천성, 후천성 및 재발잔류성(recidivistic) 유형으로 크게 분류할 수 있고, ${ }^{4)}$ 수술 후 재발하거나 잔존하는 재발잔류성 진주종의 발생률은 진주종 수술예의 10 30\%로 알려져 있다. 수술 후 재발 여부 확인은 정기적 검 진 및 영상 검사를 통해 판단해야 하고 필요한 경우 재수술 을 시행해야 한다. ${ }^{5)}$

\section{진주종 임상 양상과 수술법에 대한 국내외 많은 선행 연구들}


이 있었고, 대규모 수술 예를 기반으로 시행한 연구는 Brown ${ }^{6}$ 의 진주종 1000 명을 대상으로 시행했던 연구와 Pareschi 등 ${ }^{7)}$ 의 진주종 1445 명에 대해 시행한 연구를 들 수 있다. 한편, 국 내에서는 대규모의 진주종 연구가 많지 않은 상태이며 특히, 재발잔류성 진주종의 치료 결과에 대한 연구는 국내외적으로 미비한 실정이다.

본 연구에서는 30년간 단일 술자에 의해서 시행된 5000예 이상의 만성중이염 수술 예 중에 재발잔류성 진주종으로 진 단받고 치료받은 예를 대상으로 술전 술후 결과를 분석하고 기존의 연구 결과와 비교함으로써 이 질환의 예후와 수술 접 근법에 대해 고찰하고자 하였다.

\section{대상 및 방법}

\section{대 상}

1989년 3월 2018년 12월까지 한림대학교 강동성심병원과 한림대성심병원 이비인후과에서 단일 술자에 의해 시행된 5245예의 만성중이염 수술 중 진주종 진단 하에 수술 받은 1335예(25\%)를 연구대상으로 하였다. 전체 만성중이염 수술 중 재수술은 612예(12\%)였고, 재발된 진주종을 위한 수술은 229 예(전체의 5\%, 진주종 중 $17 \%$, 재수술 중 $37 \%$ )이었다 (Fig. 1). 재발된 진주종 229예의 수술기록을 포함한 의무기 록과 함께 2005년 대한이과학회에서 배포한 중이수술 데이 터베이스에 저장된 전산화 자료를 후향적으로 검토하여 수술 후 3개월 이상 추적 관찰이 되지 않았거나 수술 후 청력 검사 를 시행하지 않은 경우는 연구에서 제외하였고, 최종 138예 가 연구대상에 포함되었다.

\section{방 법}

수술 결과로서 수술 후 3개월 이상의 추적 후 청력개선 정 도와 수술 후 재발, 즉, 진주종 재발, 고막 재천공, 지속적 이 루를 보이는 감염증의 발생 비율을 측정하였고, 그 결과를
술전과 술후, 수술방법, 그리고, 진주종 유형 간에 비교 분석 하였다.

술전 술후 청력수준은 순음청력검사상 기도청력과 골도청 력 별로 $0.5,1,2$ 및 $3 \mathrm{kHz}$ 의 평균, 즉, 4분법을 이용하여 평 균역치를 계산하였고, 술후 청력개선은 수술 전과 후의 순음 청력역치와 술후 기도-골도 역치차(air-bone gap, ABG)를 비교하여 개선 정도를 분석하였으며 2005년 대한이과학회에 서 제안된 술후청력결과보고 지침 ${ }^{8)}$ 에 따라 정리하였다. 즉, 술후 $\mathrm{ABG}$ 가 $20 \mathrm{~dB}$ 이하, 또는 기도 청력역치(air conduction threshold)가 $30 \mathrm{~dB}$ 이하, 또는 기도 청력역치 개선이 $15 \mathrm{~dB}$ 이상인 세 가지 조건 중 하나가 충족되면 “술후 청력성공”으 로서 평가하고, 이와 함께 $\mathrm{ABG}$ 값이 0 10 dB이면 excellent result, 11 20 dB이면 good result, 21 30 dB이면 no improvement, $31 \mathrm{~dB}$ 이상이면 poor result 4가지 군으로 분류 하여 청력개선 여부를 평가하였다.

수술 후 재발은 진주종이 재수술 후에 다시 재발하여 수 술을 받은 예, 술후 3 개월 이후까지 고막 재천공이 지속된 예, 그리고, 지속적 이루, 통증 같은 감염 증세가 조절되지 않아 입원하여 항생제 치료를 받은 예를 각각 술후 진주종 재발, 고막천공, 감염 군에 포함시켰다.

통계학적 유의성 검사로서 chi-square test, Fisher's exact test, Wilcoxon signed rank test, 대응 표본 t-test를 사용하 였고 $p$ value 0.05 미만을 유의수준으로 판정하였다. 본 연구 는 한림대학교성심병원 임상연구심의위원회(IRB)의 연구승 인(승인번호: 2019-10-006) 후에 수행되었다.

\section{결 과}

연구에 포함된 138예의 평균 연령은 $38.8 \pm 17.0$ 세로 남자 62명(44.9\%), 여자 76명(55.1\%)으로 여자가 1.23배 많았으며, 수술 측 귀는 우측이 73명(52.9\%), 좌측이 65명(47.1\%)으로 우 측이 1.12 배 더 많았다(Table 1). 최소 추적 관찰 기간은 3 개 월, 최장은 18 년이었으며 평균 추적 관찰 기간은 6.0 년으로

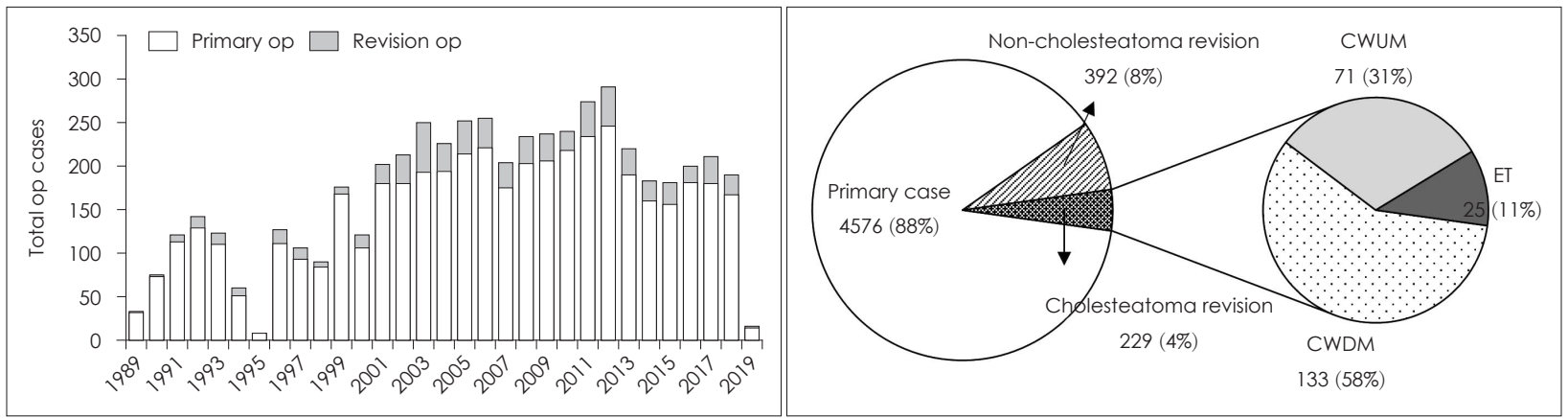

Fig. 1. Trend of 5245 cases of chronic otitis media surgery from 1989 to 2018 . Of total surgeries, $12 \%$ were revision cases and $4 \%$ had undergone surgeries due to recurred cholesteatoma. op: operation, CWUM: canal wall up mastoidectomy, CWDM: canal wall down mastoidectomy, ET: exploratory tympanotomy. 
확인되었다. 본 연구에서 사용한 수술방법으로서 개방동유 양돌기절제술(canal wall up mastoidectomy, CWUM) 38예 (27.5\%), 폐쇄동유양돌기절제술(canal wall down mastoidectomy, CWDM) 89예(64.5\%) 및 시험적고실개방술(exploratory tympanotomy, ET) 11예(8.0\%)로 구분되었고, 진주종의 유형 을 선천성과 후천성으로서 구분하였을 때 각각 14예(10.1\%)와 124예(89.9\%)로 분포되었다. 138예 중 이전 수술에 관한 정

Table 1. Demograhics of patients $(n=138)$

\begin{tabular}{lc}
\hline Mean age $( \pm$ SD), years & $38.8( \pm 17.0)$ \\
Sex, $\mathrm{n}(\%)$ & $62(44.9)$ \\
Male & $76(55.1)$ \\
Female & \\
Side, $\mathrm{n}(\%)$ & $73(52.9)$ \\
$\quad$ Right & $65(47.1)$ \\
Left & \\
Type, $\mathrm{n}(\%)$ & $14(10.1)$ \\
Congenital & $124(89.9)$ \\
Acquired & \\
Surgical procedures, $\mathrm{n}(\%)$ & $38(27.5)$ \\
CWUM & $89(64.5)$ \\
CWDM & $11(8.0)$ \\
ET & \\
Audiogram ( \pm SD), dB & $23.8(17.5)$ \\
Bone conduction & $48.1(23.5)$ \\
Air conduction & $28.1(13.0)$ \\
Air-bone gap &
\end{tabular}

SD: standard deviation, CWUM: canal wall up mastoidectomy, CWDM: canal wall down mastoidectomy, ET: exploratory tympanotomy
보가 있었던 경우가 121예였으며, CWUM이 100예(82.6\%), CWDM이 16예(13.2\%), ET가 5예(4.1\%)를 차지하였다.

전체 대상군 138 예의 수술 전 골도청력역치는 $23.8 \pm 18.5$ $\mathrm{dB}$, 기도청력역치는 $52.1 \pm 23.5 \mathrm{~dB}$ 이고, 수술 후 골도청력역 치는 $23.9 \pm 17.5 \mathrm{~dB}$, 기도청력역치는 $48.1 \pm 24.7 \mathrm{~dB}$ 로 측정되 어 술전, 술후 골도청력은 차이가 없었으나 기도청력은 수술 후에 평균 $4 \pm 13.7 \mathrm{~dB}$ 호전되었고, 통계적으로 유의하였다 $(p=$ 0.001). 이 결과를 첫번째 수술을 시행 받은 환자군과 비교했 을 때, 수술 전 골도청력 및 기도청력은 거의 유사한 수치를 보 였으나 수술 후 골도 청력은 $21.5 \pm 16.7 \mathrm{~dB}$, 기도청력은 $44.7 \pm$ $22.0 \mathrm{~dB}$ 로 수술 후 기도 청력이 평균 $7.5 \pm 13.9 \mathrm{~dB}$ 호전된 것 으로 측정되어 재수술을 시행 받은 경우가 호전이 적은 것으 로 나타났다(Fig. 2).

2005년 대한이과학회 술후청력결과보고 지침에 따라 분석 하였을 때 술후 청력성공은 총 70예(51\%)에서 한 가지 이상 의 조건을 충족하였다(Fig. 3). $\mathrm{ABG}$ 값을 이용한 술후청력 개 선정도는 excellent result 19예(14\%), good result 40예(29\%), no improvement 30예(22\%) 및 poor result 49예(36\%)로 분 류되었다(Table 2).

수술방법에 따른 술후 청력개선 정도를 비교하였을 때 CWUM 군은 38예 중 27예(71\%)에서 술후 청력성공을 보였 던 것에 비해 CWDM 군은 89예 중 37예(42\%)에서 술후 청 력성공을 보여 통계적으로 유의한 차이를 보였다. $\mathrm{ABG}$ 등급 으로 평가하였을 때 CWDM군에서 CWUM군과 ET군에 비 해 불량한 술후 청력성공 비율을 보였으나 통계적으로 유의 하지 않았다(Fig. 4).
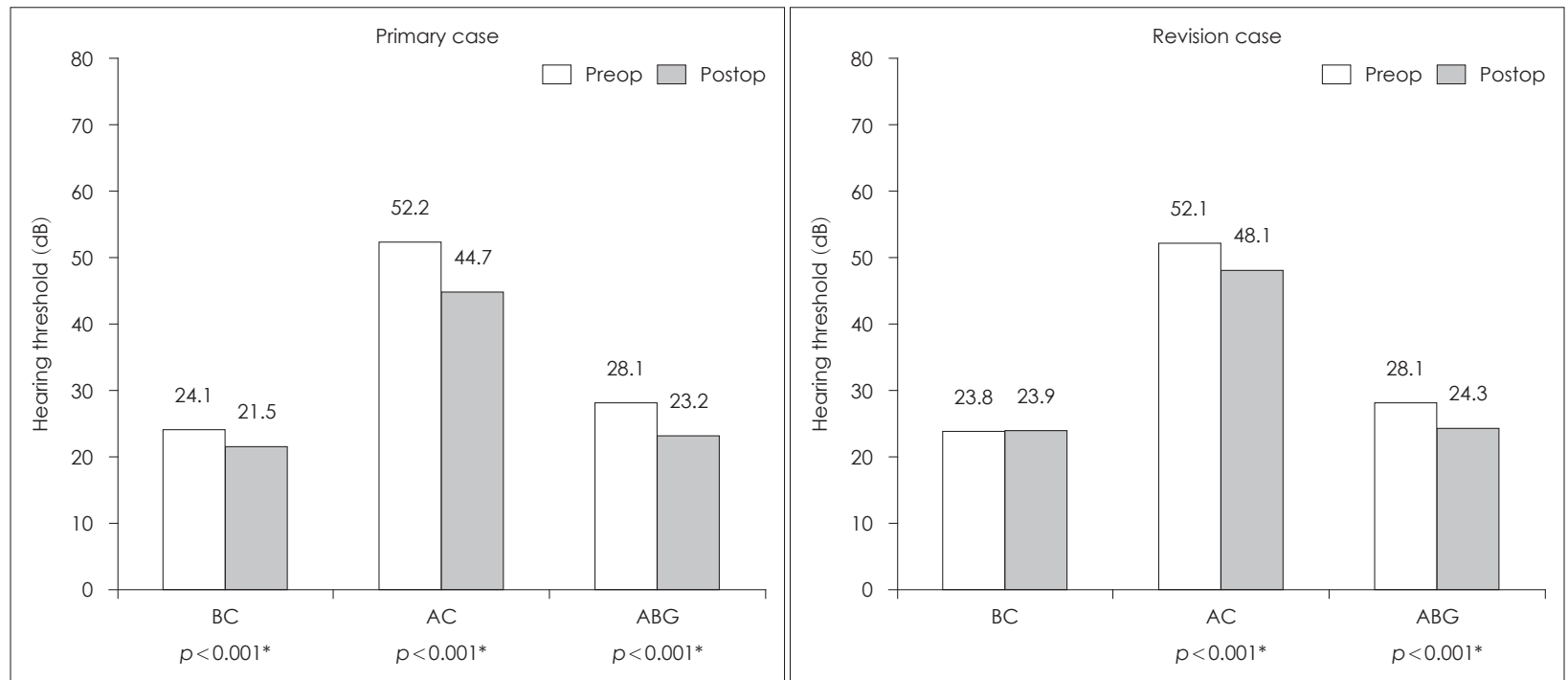

Fig. 2. Preoperative and postoperative hearing results of primary and revision cases. Both cases showed significant improvement, but hearing in the primary case was more effectively improved. preop: preoperative, postop: postoperative, BC: bone conduction, AC: air conduction, ABG: air-bone gap. 


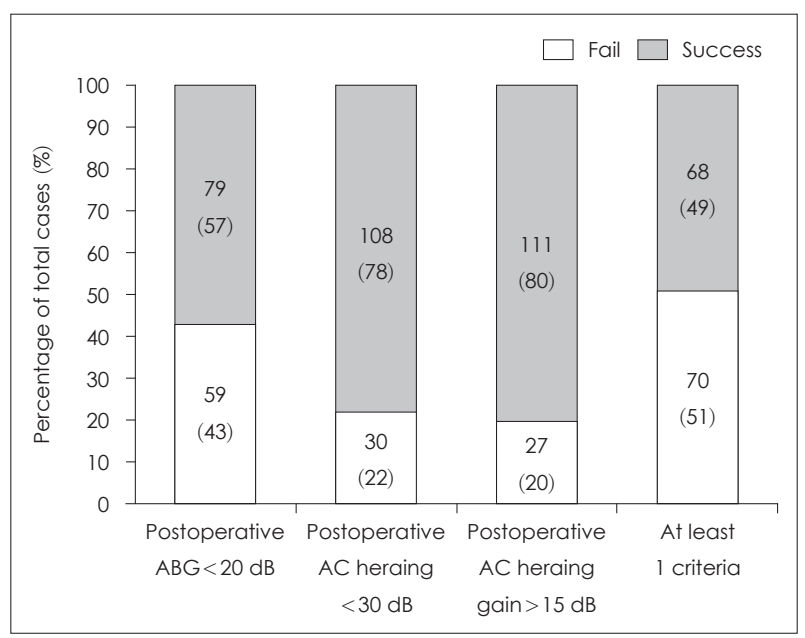

Fig. 3. Criteria for successful hearing results. Successful hearing was defined if one of the following three criteria were met (postop $A B G<20 \mathrm{~dB}$, postop $A C$ hearing gain $>15 \mathrm{~dB}$, or postop $A C$ hearing $<30 \mathrm{~dB}$ ). 70 cases were considered successful results. postop: postoperative, AC: air conduction, ABG: air-bone gap.

Table 2. Successful hearing results

\begin{tabular}{|c|c|}
\hline Hearing results & $\mathrm{n}(\%)$ \\
\hline Postoperative $\mathrm{ABG} \leq 20 \mathrm{~dB}$ & $59(42)$ \\
\hline Postoperative AC threshold $\leq 30 \mathrm{~dB}$ & $30(22)$ \\
\hline Postoperative $\mathrm{AC}$ threshold gain $\geq 15 \mathrm{~dB}$ & $27(20)$ \\
\hline At least 1 criteria & $70(51)$ \\
\hline 2 criteria & $32(23)$ \\
\hline 3 criteria & $7(5)$ \\
\hline \multicolumn{2}{|l|}{ Postoperative ABG } \\
\hline Excellent $(0-10 \mathrm{~dB})$ & $19(14)$ \\
\hline Good $(11-20 \mathrm{~dB})$ & $40(29)$ \\
\hline No improvement (21-30 dB) & $30(22)$ \\
\hline Poor (greater than $30 \mathrm{~dB}$ ) & $49(36)$ \\
\hline
\end{tabular}

$\mathrm{ABG}$ : air-bone gap, $\mathrm{AC}$ : air conduction
진주종 유형에 따른 술후 청력개선 정도를 비교하였을 때 선천성 진주종군은 14 예 중 10예(71\%)에서 술후 청력성공을 보였고, 후천성 진주종군은 114예 중 60예(48\%)로 술후 청력 성공을 보였으며 $\mathrm{ABG}$ 등급으로 평가하였을 때 선천성 군의 10예(71\%)와 후천성 군의 49예(40\%)에서 excellent result와 good result에 속하는 술후 $\mathrm{ABG}$ 값으로 측정되어 선천성 군 이 후천성 군의 청력개선 정도보다 더 좋은 것으로 관찰되었 지만 통계적 유의성은 보이지 않았다(Fig. 5).

청력결과 이외 술후 재발 결과를 평가하였을 때 138예 중 6예는 술후 재천공 소견을 보였고, 5예는 지속적 이루나 감염 으로 입원치료를 받았고 5 예는 진주종 재발로 3 번째 재수술 을 시행 받아 총 16예(12\%)의 재발 소견을 보였다. 이상의 재 발률 결과를 수술방법과 진주종 유형에 따라 분석하였을 때 각 군은 유의미한 차이를 보이지 않았다(Fig. 6).

본 연구와 더불어 같은 모집단을 대상으로 비-진주종성 만성 중이염의 재수술에 대한 결과 분석도 함께 진행되었는 데(unpublished data), 대상군 297예에서 8.3 $\pm 12.1 \mathrm{~dB}$ 의 기 도청력 호전 및 $7.8 \pm 11.7 \mathrm{~dB}$ 의 $\mathrm{ABG}$ 호전을 보였으며 $(p<$ 0.05), 본 연구와 같은 기준을 적용하였을 때 297예 중 197예 (67\%)에서 성공적인 청력 호전을 보였고. ABG 등급은 excellent result 또는 good result에 해당하는 경우가 181예(61\%) 였다. 술후 재발률을 분석하였을 때 297예 중 260예(88\%)에 서 성공적인 예후를 보여 본 연구의 결과와 차이를 보이지 않았다.

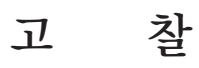

본 연구는 비교적 대규모인 5000여건의 만성중이염 수술
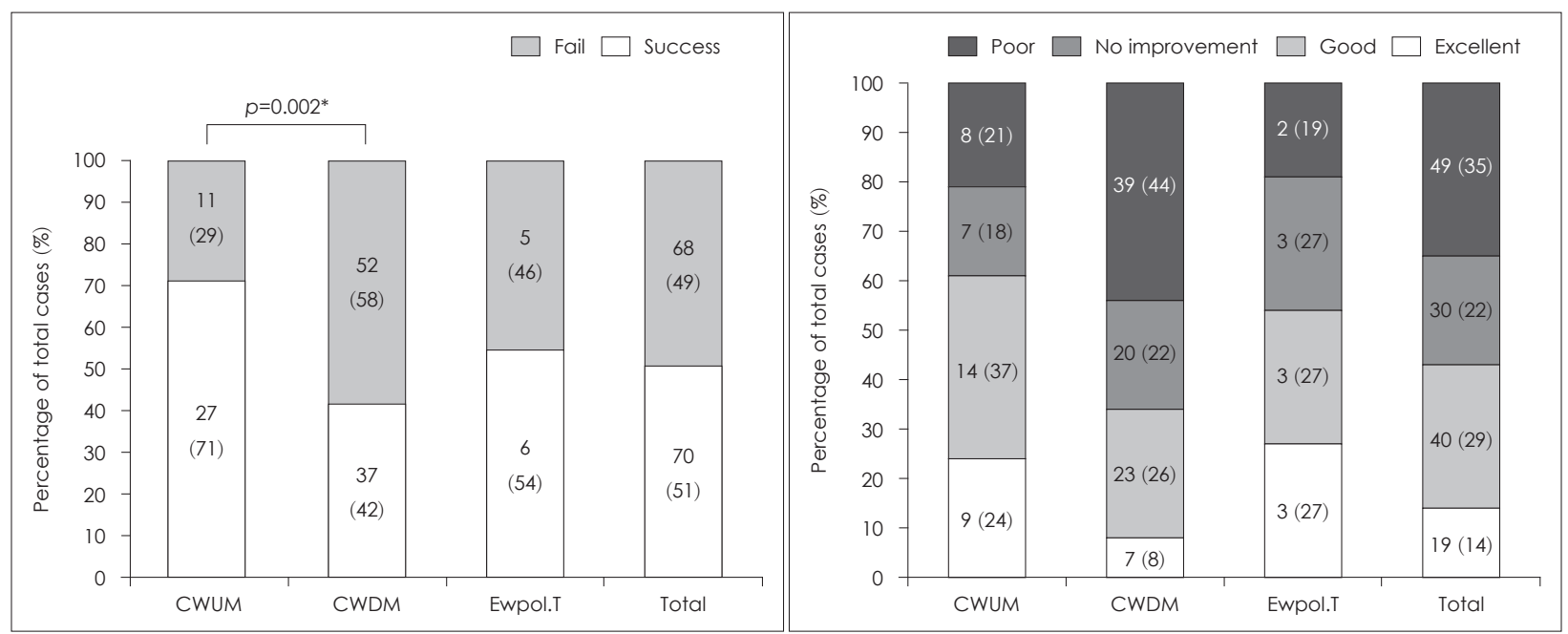

Fig. 4. Hearing results according to surgical methods. Hearing success and ABG grade according to the forementioned criteria were indicated according to the surgical method. CWUM: canal wall up mastoidectomy, CWDM: canal wall down mastoidectomy, Explo.T: explorative tympanotomy. 


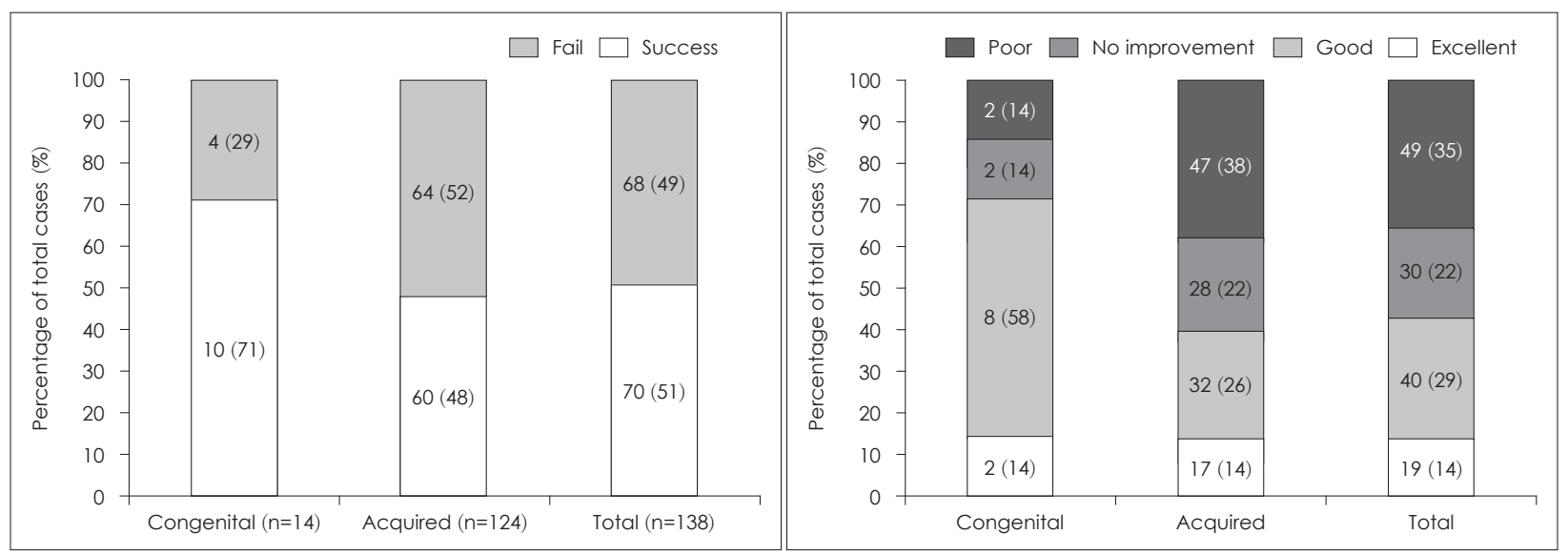

Fig. 5. Hearing results according to type of cholesteatoma.

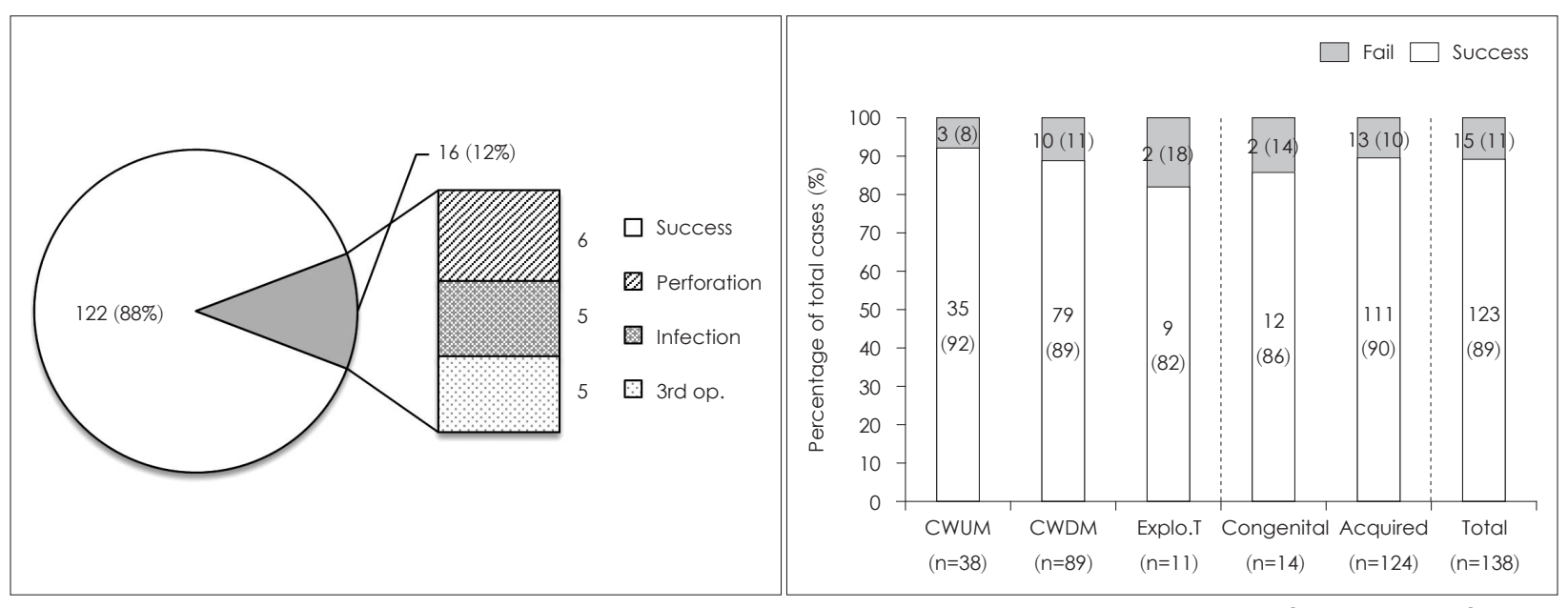

Fig. 6. Postop results other than hearing. Postop results were evaluated according to reoperation, postop infection and perforation. CWUM: canal wall up mastoidectomy, CWDM: canal wall down mastoidectomy, Explo.T: explorative tympanotomy, postop: postoperative.

예를 대상으로 진행되었다. 수술 방법의 분포는 CWUM를 시 행한 경우가 2934건(56\%), CWDM가 885건(17\%), 그 외의 수 술법이 1426건(27\%)를 차지하였고, 진주종성으로 수술 받은 1335예만을 포함하였을 때 CWUM가 623건(47\%), CWDM이 636명(48\%), ET가 76건(5\%)로 시행되었으며, 본 연구대상인 재발잔류성 진주종에서는 CWUM이 71건(31\%), CWDM이 133건(58\%), ET가 25건(11\%)를 차지하여 일차 수술보다 재발 된 진주종의 수술에서 CWDM가 상대적으로 많이 시행되었 음을 확인할 수 있었다. Tomlin 등의 의 메타연구에서 4720명 진주종 수술 중 CWUM 2761예(58\%)와 CWDM 1959예 (42\%)의 비율을 고려했을 때 본 연구의 진주종 일차수술 방 법은 큰 차이를 보이지 않았으나, Weiss 등이 의 재발성 진주 종 수술 연구에서 116예 중 CWDM 88예(75\%), CWUM 10예 (9\%) 및 ET 15예(13\%)의 비율과 비교했을 때, 본 연구에서 재수술 시 $\mathrm{CWDM}$ 를 시행하는 비중이 더 적었다.

청력개선의 정도는 대한이과학회가 제안한 기준에 따라
전체 138예 중 70예(51\%)에서 성공적인 청력개선을 보였고 $\mathrm{ABG}$ 등급으로 excellent result와 good result에 59예(43\%) 가 해당하였으며 청력 개선의 수치는 평균 $4 \pm 13.7 \mathrm{~dB}$ 정도 로 수술 전후에 큰 호전을 보이지 않았다. 이것은 첫번째 진 주종 수술 후 청력결과에 비교하면 불량한 결과로 재수술 후 청력 결과가 좋지 않음을 시사한다. 또한, CWDM 군에서 다른 군에 비해 불량한 청력 개선의 정도를 보였는데 일반적 으로 더 심한 병변에서 $\mathrm{CWDM}$ 가 빈번하게 시행되었고, 상 대적으로 결과가 좋은 선천성 군에서 주로 CWUM이 시행되 었기 때문에 청력개선의 정도에 영향을 준 것으로 생각된다. 진주종 수술로서 CWUM와 CWDM에 대한 비교는 많은 연 구에서 진행되어 왔으며 여러 선행 연구에서 폐쇄동 술식이 개방동 술식에 대해 좋은 청력 예후를 보이나 염증 조절과 재발률에 있어서는 개방동 술식이 더 유리한 것으로 나타났 다. ${ }^{67,9,11,12)}$ Tomlin 등 ${ }^{9}$ 은 진주종 환자에게 시행한 두 가지 수 술법의 결과를 메타 분석하였고 13 개 연구를 비교 분석하였 
을 때 폐쇄동 술식이 개방동에 비해서 재발 상대 위험도가 2.87 배 높다고 하였고, 이러한 재발률을 바탕으로 진주종 수 술 방법을 선택할 때 initial treatment로 CWDM를 시행하 는 것이 더 합당하다고 권고하였다. Kerckhoffs 등히이 진주 종 수술법에 따른 결과를 systemic review로 분석한 연구에 서도 CWUM를 시행한 군에서 16.7 61.0\%의 재발률을 보였 고 $\mathrm{CWDM}$ 를 시행한 군에서 0 13.2\%의 재발률을 보여 진주 종에 대한 수술법으로 $\mathrm{CWDM}$ 를 시행하는 것을 권고하였으 나 환자의 청력 정도나 보건 진료에 대한 접근성 등 다른 요인 들을 고려하여 수술법을 결정해야 한다고 결론지었다. 이와 반대로, Stankovic 등 ${ }^{14}$ 이 600여 case를 대상으로 한 연구에 서는 CWUM을 시행했던 360예 중 7.8\%에서, CWDM에서는 298예 중 22.1\%에서 재발 잔류 소견을 보여 다른 연구들과는 다른 결과를 보였다. 본 연구에서는 수술 방법에 따른 재발 률은 유의한 차이가 없었는데, 일반적으로 병변이 심한 진주 종 예에서 $\mathrm{CWDM}$ 를 시행하는 경우가 많기 때문에 CWDM 에서 심한 병변으로 인한 재발률이 더 높을 수가 있고 성공 적인 청력개선이 높지 않은 결과 역시 이와 관련 있을 것으로 사료된다. 재발 여부는 환자의 이관 기능, 기저질환 등에도 영향을 받을 수 있기 때문에 수술 방법에 따른 재발률이 연 구마다 다르게 보고된 것으로 보인다. 또한, 평균 추적 관찰 기간이 짧아서 진주종 재발에 대한 평가가 미흡하다는 점 또 한 재발률을 평가하는 데에 있어 제한점이 될 수 있을 것으 로 사료된다.

진주종 유형에 따른 결과는 여러 원발성 진주종의 연구에 서 알려져 있는 바와 같이 재발성 진주종에서도 선천성 진주 종 군에서 청력 결과가 더 좋은 것으로 나타났으나 연구대상 수가 적어 통계적으로 유의한 차이는 보이지 않았던 것으로 생각된다. 수술 후 재발률 예후에 대한 분석에서는 122예 (88\%)에서 성공적인 예후를 보였고 천공, 지속적 이루, 진주 종 재발 소견을 보인 경우는 16예(12\%)를 차지하였다. Weiss 등미 이 시행했던 연구에서는 재발 잔류성 진주종에 대한 재 수술 116예 중 수술 후 4예(3\%)에서 재발, 7예(6\%)에서 수술 후 이루, 5예(4\%)에서 천공 소견을 보였고 39예(35\%)에서 10 $\mathrm{dB}$ 이상의 청력 호전을 보여 본 연구와 결과가 비슷함을 확 인할 수 있었다.

본 연구와 더불어 시행한 비-진주종성 만성 중이염의 재 수술에 대한 결과를 비교해 보았을 때 비-진주종성 만성 중 이염 재수술 후 청력 결과가 재발한 진주종성 중이염의 재수 술의 경우에 비해 평균 청력 역치의 호전 정도가 컸으며, 성 공적인 청력 개선을 보인 비율이 높았으며, 재발률은 두 집단 사이에 통계적으로 유의한 차이가 없었다.

본 연구는 아직까지 연구가 활발치 않았던 재발잔류성 진
주종의 치료 결과를 단일 술자에 의한 대규모 수술자료를 통 해 분석을 했다는 점을 들 수 있고, 향후 유사한 연구를 할 때 배경자료로서 활용할 수 있을 것으로 생각된다. 다만, 연 구의 제한점으로 첫째, 30 년의 의무기록을 통한 후향적 연구 특성상 자료 미비로 인한 정확한 재발률 조사가 어려웠고, 둘째, 최소 청력추적기간이 3 개월로 짧았던 점을 들 수 있다. 본 연구에서 수술 방법에 있어서 CWUM, CWDM 및 ET의 세 군으로만 분류를 하였고, tympanoplasty 등 기타 술기에 대한 분석이 없었다는 점은 향후 추가 연구로 보완해야 할 부분이다.

재발잔류성 진주종에서 개방형유양돌기절제술이 더 흔히 시행되는 것으로 나타났고 개방형유양돌기절제술을 시행했 던 군에서 대조군에 비해 청력 결과가 대체적으로 불량한 것 으로 나타났다. 수술 후 재발 발생률은 $12 \%$ 로 측정되었고 수 술 종류별 그룹 간의 차이는 보이지 않았다. 이러한 결과들은 수술 전 환자 상담과 수술 후 결과를 예측할 수 있는 자료로 서 활용할 수 있을 것으로 생각된다.

\section{Acknowledgments}

This study was supported by the National Research Foundation of Korea (NRF) grant funded by the Korean Government (2018R1D1A1B07045305).

\section{Author Contribution}

Conceptualization: Hyung-Jong Kim. Data curation: Ji Soo Lee. Formal analysis: Ju Ho Han. Project administration: Sung Kwang Hong. Supervision: Hyo Jeong Lee. Writing — original draft: Ji Soo Lee. Writing — review \& editing: Hyung-Jong Kim.

\section{ORCID}

Hyung-Jong Kim ～https://orcid.org/0000-0001-9020-6026

\section{REFERENCES}

1) Kim CS, Jung HW, Yoo KY. Prevalence and risk factors of chronic otitis media in Korea: Results of a nation-wide survey. Acta Otolaryngol 1993;113(3):369-75.

2) Cho YS, Choi SH, Park KH, Park HJ, Kim JW, Moon IJ, et al. Prevalence of otolaryngologic diseases in South Korea: Data from the Korea national health and nutrition examination survey 2008. Clin Exp Otorhinolaryngol 2010;3(4):183-93.

3) Lee JM, Rha MS, Park JJ, Kim SH. A case of recurred cholesteatoma removal via middle cranial fossa approach. Korean J Otorhinolaryngol-Head Neck Surg 2015;58(5):359-63.

4) Neudert M, Lailach S, Lasurashvili N, Kemper M, Beleites T, Zahnert T. Cholesteatoma recidivism: Comparison of three different surgical techniques. Otol Neurotol 2014;35(10):1801-8.

5) Roger G, Denoyelle F, Chauvin P, Schlegel-Stuhl N, Garabedian EN. Predictive risk factors of residual cholesteatoma in children: A study of 256 cases. Am J Otol 1997;18(5):550-8.

6) Brown JS. A ten year statistical follow-up of 1142 consecutive cases of cholesteatoma: The closed vs. the open technique. Laryngoscope 1982;92(4):390-6.

7) Pareschi R, Lepera D, Nucci R. Canal wall down approach for tympano-mastoid cholesteatoma: Long-term results and prognostic 
factors. Acta Otorhinolaryngol Ital 2019;39(2):122-9

8) Kim HJ. Classification and hearing result reporting guideline in chronic otitis media surgery. Korean J Otorhinolaryngol-Head Neck Surg 2006;49(1):2-6.

9) Tomlin J, Chang D, McCutcheon B, Harris J. Surgical technique and recurrence in cholesteatoma: A meta-analysis. Audiol Neurootol 2013;18(3):135-42.

10) Weiss MH, Parisier SC, Han JC, Edelstein DR. Surgery for recurrent and residual cholesteatoma. Laryngoscope 1992;102(2):145-51.

11) Moss R, Lucente FE. Results in resident cholesteatoma surgery: A review of 85 cases. Laryngoscope 1987;97(2):212-4.

12) Syms MJ, Luxford WM. Management of cholesteatoma: Status of the canal wall. Laryngoscope 2003;113(3):443-8.

13) Kerckhoffs KG, Kommer MB, van Strien TH, Visscher SJ, Bruijnzeel H, Smit AL, et al. The disease recurrence rate after the canal wall up or canal wall down technique in adults. Laryngoscope 2016;126(4):980-7.

14) Stankovic M. Follow-up of cholesteatoma surgery: Open versus closed tympanoplasty. ORL J Otorhinolaryngol Relat Spec 2007; 69(5):299-305. 